The conference will try to improve industry's scientific reputation among science teachers, in the hope that some of their enthusiasm will filter through to their pupils. To this end the conference will mainly consist of a series of lectures on various aspects of contemporary industrial chemistry, designed to illustrate the volume and quality of industrial research.

The Royal Society is sponsoring the meeting through the British National Committee for Chemistry. The majority of the speakers come from the chemical and allied industries, which are also paying for the conference. The speakers include Lord Beeching, a deputy chairman of ICI, Lord Sherfield, chairman of the Industrial and Commercial Finance Corporation, and Dr M. E. Spaght, a managing director of the Royal Dutch Shell Group. The president of the conference is Lord Todd, professor of organic chemistry at the University of Cambridge.

This is not the first conference to be held along these lines. The Science Research Council, in association with the Careers Research and Advisory Centre, staged an experimental summer school in Oxford last year to persuade postgraduate students carrying out research in university science departments to consider management as a career. The students and the managers from industry who attended must have benefited from the free exchange of ideas encouraged by a summer school.

It is difficult to see how a similar exchange of views, essential if managers are to become more aware of the academic scientist's impression of industry, will be possible within the formal framework of the Eastbourne meeting. The chemical industry is nevertheless probably correct in realizing the important part played by the schools in influencing choice of careers. If it can demonstrate to the teachers that industrial research is as challenging and as intellectually demanding as academic work, it may go some way towards helping its own recruitment of scientists.

\section{Whence Foot and Mouth?}

LAMB from Argentina was the probable source of the British foot-and-mouth epidemic that first broke out on a Shropshire farm last October and has since led to the slaughter of some 443,000 animals. This conclusion-hotly disputed by the Argentinian Embassy in London-is made in the report compiled by the Ministry of Agriculture and published this week.

The report bases its case on the circumstantial evidence that Argentine lamb was supplied to the farm where the epidemic first began, and on the failure to discover any other possible source of infection. In an admirably thorough piece of detection, Mr John Reid, the Ministry's chief veterinary officer, has established that the disease could not have been introduced to the Shropshire farm by the movement of humans or animals, and he considers that, although there were 3,000 cases of the disease last year in Western Germany, it could not have been transmitted either by the winds or by birds. "The distance is too great for the disease to have been brought from Germany to Shropshire by birds", he says, and presumably - though this is not stated in the report-the route does not correspond to any migratory pattern.

Ruling out imported hay and a previous outbreak of the disease in Warwickshire, Mr Reid narrows down the possible source of infection to imported meat. The butcher who supplied meat to the Shropshire farm received New Zealand lamb and Argentine lamb from his distributor. It is not known which kind of lamb the farm received, but New Zealand is free from foot-and-mouth whereas in Argentina the disease is endemic. The owner of the farm fed bones to his dogs and although he boiled them first he "did not claim that this was always done effectively". The disease first broke out in two gilt pigs and the bones fed to the dogs "could have been carried into the yard or neighbouring ficlds where the gilts had been". From this reconstruction of the crime, the report says, "it was not possible to establish conclusively that imported frozen lamb carried foot-and-mouth disease virus to the farm, but, as all other generally recognized sources of infection had been eliminated, it remained the most probable vector". The majority of subsequent outbreaks were probably the result of carriage by birds and the wind, but the large number of cases which occurred simultaneously over a wide area suggests a common primary cause. The Argentine lamb supplied to the Shropshire farm came from a consignment of 770 carcasses, all from a particular establishment in the Argentine, which was distributed over a wide area of the country. This was the area of the greatest concentration of the infection in the first month of the epidcmic.

The only type of virus isolated in the epidemic was $\mathrm{O}_{1}$. Although this type is prevalent in South America, it is not yet known whether it is prevalent in the area which supplies the establishment from which the suspected consignment was supplied.

How did the virus bypass the measures for its detection? The Argentinian Embassy in London has pointed out that there is a permanent veterinary staff attached to the British Embassy in the Argentine which collaborates with the local authorities in inspecting hygienic conditions in canning factories and slaughter houses. The staff was established on the recommendation of the Gowers Report, presented in 1954 after the last serious outbreak of the disease in Britain, but it has no power to sample carcasses intended for export to Britain for the disease. This, the British Ministry of Agriculture has stated, is the responsibility of the Argentinian Veterinary Service. It is impracticable to sample the carcasses coming into Britain because the heads and feet, which bear the most obvious signs of the disease, have been removed.

The most recent cases of the present epidemic occurred on February 21. The Ministry of Agriculture hopes that these will be the last, but is keeping its fingers crossed until the three-week incubation period of the virus has passed.

\section{Carnegie Research}

A REVIEW of the research being done at the six research departments of the Carnegie Institution of Washington is given in the institution's latest annual report for 1966-67. The departments concerned are the Geophysical Laboratory and the Department of Terrestrial Magnetism, both in Washington, DC; the Department of Plant Biology at Stanford, California; the Department of Embryology at Baltimore, Maryland; the Genetics Research Unit, Cold Spring Harbor, New York; and the Mount Wilson and Palomar Observa- 